\title{
The Effect of Equity Concentration, Dual Listing and Audit Quality on Stock Price Synchronicity
}

\author{
Xingcun $\mathrm{Hu}$ \\ School of Finance \\ Shandong University of Finance and Economics \\ Ji'nan, China 250014
}

\author{
Yongfan Ma \\ School of Finance \\ Shandong University of Finance and Economics \\ Ji'nan, China 250014
}

\begin{abstract}
This paper studies the impact of stock concentration, dual listing and audit quality on the stock price synchronicity of listed companies in China during the period from 2009 to 2018. Using unbalanced panel data, this paper concludes that stock price synchronicity is a concave function of equity concentration, and that foreign ownership and high quality audits will effectively reduce the synchronicity of stock prices and make the market more effective.
\end{abstract}

Keywords—equity concentration; dual listing; audit quality; stock price synchronicity

\section{INTRODUCTION}

As a typical representative of emerging capital markets, China's stock market volatility and changes have received widespread attention. As a direct variable to measure stock market volatility, stock price can better reflect the operational efficiency and standardization of a country's capital market. Through years of research on the price trend of individual stocks in China's stock market, there is a more obvious market characteristic in China's stock market - the phenomenon of "same rise and fall".

The emergence of this phenomenon of "same rise and fall" reflects the ineffectiveness of the market to a certain extent. Because stock prices are variables that reflect the company's trait information, there is no theoretically strong correlation between them, and their pricing and trends. The emergence of the phenomenon of "same rise and fall" means that the company's trait information is difficult to reflect in the stock price. The company is affected by the market and industry, and it also reflects the weakening of the price discovery function of the securities market and the lack of market effectiveness.

In the stock market, corporate trait information is an important performance factor, which is mainly transmitted to investors and the public through various information disclosure methods. When investors and the public obtain information, they will judge and screen the information. When they think they have enough real and reasonable information, they will make investment decisions. At this time, the trait information will be reflected in the stock price through various investment behaviors, which will affect the stock price synchronization. This paper will focus on the three factors affecting the company's trait information and investor behavior, such as equity concentration, dual listing, and audit quality, and explore its relationship with stock price synchronicity through empirical methods.

\section{LITERATURE REVIEW}

The fluctuation of the company's stock price is mainly affected by the market, industry and company. In the 1988 study, Roll found that stock price volatility was not explained to a large extent by market factors, and the weaker the relationship between stock price and market, the smaller the explanatory power, in contrast to the company-level trait information. Being more reflected in the stock price, the more company trait information in the stock price, the lower the stock price synchronicity. Morck, Yeung and Yu (2000) used empirical methods to test the stock price synchronicity of different capital markets, and found that the more mature the market share price is less synchronized, the investors in this market are faced with a standardized market operation mechanism and a protected environment, and it is easier to obtain the company's trait information and reflect it in the stock price. The study further found that China as a representative of emerging markets, due to lack of operational norms and lack of investor protection, hindered informed trading, stock prices are more susceptible to market and industry factors, company trait information is difficult to integrate into stock prices, stock price synchronization is higher.

Based on Roll's theory, the subsequent research explores the influencing factors of stock price synchronicity from two different ideas: "company trait information" and "irrational factors".

\section{A. The "Information Efficiency Concept" of Stock Price Synchronization}

The research representative of this theory is MYY (2000), he believes that the degree of integration of company trait information into stock price determines the level of stock price synchronization. That is, the more company trait information is integrated into stock price, the lower the stock price synchronization. Subsequently, Li et.al (2004) focused on the judicial system of the capital market and the level of openness, studied the correlation with stock price synchronicity, and found that the more perfect the judicial system of the capital market, the higher the level of opening 
up to the country or region, the lower the stock price synchronicity. Piotroski et.al (2004) and Chan et.al (2006) found that stock market synchronicity in emerging markets is higher because listed companies in the market disclose lower trait information and the cost of obtaining this information and then judging the accuracy of the investor is high, and these two factors together lead to an increase in the synchronicity of the stock price.

According to the research results of "information efficiency concept", stock price synchronism has the function of measuring the degree of corporate trait information disclosure in the stock market. The theory holds that higher stock price synchronicity not only reflects the lack of corporate trait information in asset pricing, but also leads to the convergence of listed companies, weakens the role of stock price as a means of information transfer, and is not conducive to investors making accurate investment decisions and reducing the effectiveness of capital markets. According to Durnev et al. (2004), stock price synchronization will affect the company's management decisions. In markets with low stock price synchronization, the trait information of company decisions will be more clearly reflected in the stock price, which will make management more cautious in making investment decisions and improve the scientific nature of decision making. Jin and Myers (2006) found that when listed companies publish transparent and complete financial information, which will increase the accounting information in the stock price and reduce the stock price synchronization. The "information efficiency concept" has also been supported by most scholars in China. Yu Jiaxing (2008) combined with the foreign scholar Wurlger's capital allocation efficiency model, using the data of China's stock market from 2001 to 2005, studied the relationship between capital allocation efficiency and stock price synchronicity, and found that capital prefers high-efficiency securities market, securities market, and the lower the stock price synchronization, the higher the efficiency of capital allocation. Xiao Hao (2011) used the arbitrage model to prove that mature institutional investors can make more rational investment decisions and reduce stock price synchronization because of their information superiority.

\section{B. The "Irrational Behavioral View" of Stock Price Synchronization}

In explaining the factors affecting stock price synchronicity, there are different interpretations of the "irrational behavior view" school represented by Wast and the "information efficiency concept" school. This view holds that investors' irrational behaviors such as "follow the crowd", "chasing up and down", the existence of market bubbles and noise affect stock prices, which in turn affect stock price synchronicity. The more noise contained in the stock price, the lower the synchronicity of the stock price. Wast (1988) believes that the stock price of listed companies with low transparency contains many irrational factors, which causes stock prices to not truly reflect the value of listed companies, which in turn leads to a large deviation in the pricing of listed companies. Lee and Liu (2007) found through empirical research that in the stock market with ideal information environment, the theory is consistent with the view of "information efficiency concept", that is, the stock price synchronization is negatively correlated with the stock price information content. When the stock market is relatively unsatisfactory in the information environment, stock price synchronicity is positively correlated with stock price information content. The conclusion based on this hypothesis is consistent with the view of "irrational behavior view".

\section{THEORETICAL DERIVATION AND RESEARCH HYPOTHESIS}

\section{A. Equity Concentration and Stock Price Synchronicity}

The current literature mainly relies on the information efficiency concept of MYY (2000) to further derive the degree of equity concentration and stock price synchronization. Many scholars believe that the decisive factor of stock price synchronicity is that the company's trait information is included in the stock price decision: when the stock price can reflect: when stock prices can reflect more real and effective information, the convergence of stock prices between companies is lower, and stock price synchronicity is smaller; on the contrary, when the stock price can reflect the actual state of the company, the phenomenon of "same rise and fall" between the companies is more common, and the stock price is more synchronized. Gul (2010), a study by many scholars at home and abroad, found that there is a non-linear relationship between equity concentration and stock price synchronicity, which is inverted U-type, that is, as the concentration of equity increases, the stock price is more synchronized. The management defense effect is greater than the synergy effect of interests and dominates. After reaching a certain turning point, the concentration of equity increases again, and the stock price synchronization gradually weakens. At this time, the synergy effect of interests is greater than the management defense effect.

On the one hand, based on the theory of behavioral finance, people are bounded rational. When the shareholding ratio of the first major shareholder rises, the material needs and spiritual needs of the company are satisfied. The performance is that the shareholders are doing a good job in the company's hard work; the company's operation and information disclosure are doing better. At this time, the company's stock price and the market's convergence are weakened. When the shareholding ratio of the largest shareholder exceeds a certain proportion, the shareholders are increasingly constrained by the managers, and more and more considerations are made for their own interests. The power to effectively limit their management behavior has become weaker. At this time, due to the need of greed or other interests, shareholders began to cover up their behavior, the effectiveness of disclosure information could not be guaranteed, and stock price synchronization began to rise.

On the other hand, based on the principal-agent theory, the ownership and management rights of the company are separated from each other, resulting in a conflict of interest 
between shareholders and managers. Managers as managers of the company may harm the interests of shareholders for their own purposes. When the equity is relatively dispersed, the power to effectively balance and supervise the manager's behavior is more dispersed, and the stock price synchronization will be higher; If the concentration is high, the shareholder's supervision of the manager is greater, which greatly reduces the possibility of harming the company's interests.

Based on the above analysis, there is a concave function relationship between stock price synchronicity and equity concentration: as equity concentration increases, it gradually changes from interest synergy effect to management defense effect.

H1a: The stock price synchronicity shows a positive Ushaped relationship with the first decrease and then increase with the increase of the concentration of the stock.

In addition, it is necessary to study whether stock price synchronicity is related to the nature of the actual controller of the listed company. Although the government has been working hard to reform its financial system and related laws and regulatory mechanisms in recent years, there are still many listed companies closely linked to the government. Most of their actual controllers are central government, local government, SASAC (State-owned Assets Supervision and Administration Commission) or local governments. Since the actual control related to the government may result in the company's supervision being in place and the governance efficiency is low, when the actual controller is related to the government, the stock price is highly synchronized.

H1b: When the actual controller of the company is government-related, the stock price is highly synchronized.

\section{B. Foreign Shareholding and Stock Price Synchronicity}

All listed companies issue tradable shares to domestic investors, known as A shares.

Some of these companies also issue shares to foreign investors. The two most popular foreign shares are B shares traded on SSE and Shenzhen Stock Exchange and H shares traded in Hong Kong. The regulatory requirements and information environment for foreign shareholders are different from those in China: From the disclosure of financial statements, listed companies that issue only A shares need to issue annual accounting statements in accordance with domestic accounting standards (DAS). At the same time, listed companies that issue B shares and $\mathrm{H}$ shares also need to issue International Financial Reporting Standards (IFRS) or Hong Kong Accounting Standards (GAAP).In terms of the quality of accounting standards, the financial reporting standards adopted by IFRS or mature developed markets such as Hong Kong in the United States are far superior to domestic accounting standards. The use of high-quality accounting standards can better clarify the financial status of the company. To a certain extent, the difficulty of fiction or forgery is increased. So it can be predicted:
H2a: For companies that are listed on both B-shares and $\mathrm{H}$-shares, share price synchronization is low.

Compared with the domestic stock market, the Hong Kong market is more mature and efficient, and the investor protection mechanism is better. Therefore, Chinese companies that issue $\mathrm{A}$ shares and $\mathrm{H}$ shares (hereinafter referred to as $\mathrm{A}+\mathrm{H}$ shares) face two different institutions and investor protection environments, namely Hong Kong and China. Chinese companies that issue $\mathrm{A}$ shares and $\mathrm{B}$ shares (hereinafter referred to as $\mathrm{A}+\mathrm{B}$ shares) are only exposed to China's institutional environment (Brockman and Chung, 2003). Given that $\mathrm{A}+\mathrm{H}$ companies are subject to a more mature Hong Kong market environment and investor protection than $\mathrm{A}+\mathrm{H}$ shares, facing greater disclosure requirements and stricter legal and regulatory enforcement, the former to have lower stock price synchronism than the latter.

$\mathrm{H} 2 \mathrm{~b}$ : The share price synchronicity of companies issuing $\mathrm{A}+\mathrm{H}$ shares is lower than that of $\mathrm{A}+\mathrm{B}$-share companies.

\section{Audit Quality and Stock Price Synchronization}

External audits reduce information asymmetry between managers and shareholders by disclosing company information such as financial statements to markets and investors (Dopuch and Simunic, 1982). As agency costs increase, so does the need for high quality audits (eg, Watts and Zimmerman, 1986; DeFond, 1992). Audit quality is often defined as the joint probability of detecting and reporting financial statement errors (DeAngelo, 1981; Choi, Kim, Liu, and Simunic, 2008). Among them, Fan and Wong (2005) report that the four major auditors play a corporate governance role in emerging markets with highly concentrated ownership structures. High-quality auditors may "force" their client companies to disclose more detailed, better-quality corporate information in a timely manner, thereby better protecting minority shareholders, and their information production activities promote inter-industry information transfer, thereby increasing Synchronization.

H3: The financial report is provided by the listed companies provided by the previous major accounting firms, and the stock price is less synchronized.

\section{MODEL CONSTRUCTION}

\section{A. Measurement of Stock Price Synchronization}

1) Conventional market model: In order to calculate the dependent variable studied in this paper, the daily yield of the company's stock is divided into two influencing factors at the market level and the industry level by referring to the research method of Gul (2010).

Model 1.1: All companies (issuing A shares, issuing A+B shares at the same time, and issuing $\mathrm{A}+\mathrm{H}$ shares at the same time) are included in the unified model, using the daily earnings rate data of listed companies, market daily yield and industry day, the rate of return and its lag period to estimate the market model. 


$$
R E T_{i t}=\alpha+\beta_{1} R_{E T a_{t}}+\beta_{2} \text { RETa }_{t-1}+\beta_{3} \text { indret }_{t}+\beta_{4} \text { indret }_{t-1}+\varepsilon_{i t}
$$

Where for the i company of $\mathrm{t}$ period, $R E T_{i t}$ indicates the stock daily return rate in the A-share market; RETa $a_{t}$ and $R E T a_{t-1}$ are the weighted market daily rate of return for the t-th and t-1 periods; indret $_{t}$ and indret $_{t-1}$ represent the daily industry yield data of the t-th and $t-1$ periods. Here, the daily return rate of A-share stocks and the daily market return rate are derived from the CSMAR database, and the industry daily yield is derived from the RESSET database. In addition, considering the potential for non-synchronous trading bias caused by the use of daily yield data, a lag in market returns and industry returns is also introduced in the market model.

2) Considering a dual listing model: In addition, in addition to the A-share market, it is necessary to use this method to estimate the stock price synchronicity of $\mathrm{A}+\mathrm{B}$ $(\mathrm{A}+\mathrm{H})$ stocks. They are:

$$
\begin{aligned}
& R E T_{i t}=\alpha+\beta_{1} R E T a_{t}+\varepsilon_{i t} \\
& R E T_{i t}=\alpha+\beta_{1} R E T a_{t}+\beta_{2} R E T b_{t}+\varepsilon_{i t} \\
& R E T_{i t}=\alpha+\beta_{1} R E T a_{t}+\beta_{2} R E T h_{t}+\varepsilon_{i t}
\end{aligned}
$$

$\mathrm{RETa}_{\mathrm{t}}$ is the weighted B-share market daily yield data calculated by the listed and Shenzhen Stock Exchange B- shares index; $\mathrm{RETh}_{\mathrm{t}}$ is the weighted Hong Kong market daily yield data calculated using the Hang Seng Index, the data is derived from the Wind database, and other variables are as described above.

After estimating equations (1) and (1a), (1b) (1c), variables representing stock price synchronism are obtained. The essence considered is the goodness of fit, the range is between $[0,1]$, not meet the requirements of least squares regression in econometrics. In order to avoid this property, this paper uses the logic transformation proposed by two scholars Dumev and Morck:

$$
\mathrm{SYNCH}_{i}=\log \left(\frac{R_{i}^{2}}{1-R_{i}^{2}}\right)
$$

The conversion estimated using equation (1) is denoted as SYNCH, and the weights estimated using equations (1a), (1b) and (1c) are converted to SYNCHabh.

\section{B. Variable Definition}

In the study of this paper, in addition to the above

\begin{tabular}{|c|c|c|c|}
\hline & Variable & Name & Definition \\
\hline \multirow[t]{2}{*}{$\begin{array}{l}\text { Explanatory } \\
\text { variable }\end{array}$} & SYNCH & $\begin{array}{l}\text { Stock price } \\
\text { indicator } 1\end{array}$ & $S Y N C H_{i}=\log \left(\frac{R_{i}^{2}}{1-R_{i}^{2}}\right)$ \\
\hline & SYNCHabh & $\begin{array}{lll}\text { Stock price } & \text { synchronization } \\
\text { indicator } 2 & \end{array}$ & $S Y N C H a b h_{i}=\log \left(\frac{R_{i}^{2}}{1-R_{i}^{2}}\right)$ \\
\hline \multirow{8}{*}{$\begin{array}{l}\text { Explanatory } \\
\text { variable }\end{array}$} & Tophold & Equity concentration indicator 1 & The shareholding ratio of the largest shareholder \\
\hline & DIF & Equity concentration indicator 2 & $\begin{array}{l}\text { The sum of the shareholding ratio of the second and } \\
\text { third largest shareholders }\end{array}$ \\
\hline & BALANCE & Equity balance indicator & $\begin{array}{l}\text { share ratio of the second to fifth largest shareholders / } \\
\text { share of the largest shareholder }\end{array}$ \\
\hline & Dumcontrol & Actual controller nature & a state-owned enterprise, dumcontrol $=1$, otherwise 0 \\
\hline & Dumab & B-share indicator & $\begin{array}{l}\text { B shares listed, } \operatorname{dum} \mathrm{AB}=1 \text {, } \\
\text { otherwise } 0\end{array}$ \\
\hline & Dumah & H-share indicator & $\begin{array}{l}\mathrm{H} \text { shares listed, } \operatorname{dum} \mathrm{AH}=1 \text {, } \\
\text { otherwise } 0\end{array}$ \\
\hline & Audit & Financial report quality & $\begin{array}{l}\text { Type of audit opinion given by the accounting firm to } \\
\text { the company's financial audit each year }\end{array}$ \\
\hline & Dadtunit & Audit quality & $\begin{array}{l}\text { "Four big" accounting firm audit, dadtunit=1, } \\
\text { otherwise } 0\end{array}$ \\
\hline \multirow{4}{*}{ Control variable } & Turnover & Stock turnover rate & $\begin{array}{l}\text { The total number of shares /the number of shares } \\
\text { outstanding }\end{array}$ \\
\hline & LEV & Asset liability ratio & Ratio of liabilities to assets \\
\hline & SIZE & Company Size & Natural logarithm of total assets \\
\hline & PB & $\mathrm{P} / \mathrm{B}$ ratio & total market value / total assets \\
\hline
\end{tabular}
mentioned variables SYNCH and SYNCHabh for measuring stock price synchrony from 2009 to 2018 , the variables in "Table I" were also selected.

TABLE I. VARIABLE DEFINITION 


\section{Regression Model}

To verify the relationship between equity concentration and stock price synchronicity (H1a) and between actual controller and stock price synchronicity $(\mathrm{H} 1 \mathrm{~b})$, it sets the following estimation model:

$$
\begin{aligned}
& \text { SYNCH }_{i t}=\gamma_{0}+\gamma_{1} \text { tophold }_{i t}{ }^{2}+\gamma_{2} \text { tophold }_{i t}+\gamma_{3} \text { dumcontrol }_{i t}+\sum_{k} \gamma_{k} \text { CONTROL }_{i t}{ }^{k} \\
& + \text { Year }+ \text { Industry }+\varepsilon_{i t}
\end{aligned}
$$

Therefore, it is assumed that H1a is equivalent to $\gamma_{1}>0$ and $\gamma_{2}<0$; hypothesis H1b is equivalent to $\gamma_{3}>0$.
In order to verify the relationship between foreign shareholding and stock price synchronicity, it assumes that $\mathrm{H} 2 \mathrm{a}$ and $\mathrm{H} 2 \mathrm{~b}$ it sets the following estimation model:

$$
\begin{aligned}
& S Y N C H_{i t}=\phi_{0}+\phi_{1} d u m A B_{i t}+\phi_{2} d u m A H_{i t}+\sum_{k} \phi_{k} \text { CONTROL }_{i t}{ }^{k} \\
& + \text { Year }+ \text { Industry }+\varepsilon_{i t}
\end{aligned}
$$

The setting of the variable is the same as described above. At this time, it is assumed that $\mathrm{H} 2 \mathrm{a}$ is equivalent to $\phi_{1}<0$ and $\phi_{2}<0 ; \mathrm{H} 2 \mathrm{~b}$ is equivalent to $\phi_{1}>\phi_{2}>0$.
Finally, in order to verify the relationship between audit quality and stock price synchronicity, it assumes that $\mathrm{H} 3$ it sets the following estimation model:

$$
\begin{aligned}
& \text { SYNCH }_{i t}=\lambda_{0}+\lambda_{1} \text { dadtunit }_{i t}+\lambda_{2} \text { audit }_{i t}+\sum_{k} \lambda_{k} \text { CONTROL }_{i t}{ }^{k}+\text { Year } \\
& + \text { Industry }+\varepsilon_{i t}
\end{aligned}
$$

The setting of the variable is the same as described above, and it is assumed that $\mathrm{H} 3$ is equivalent to $\lambda_{1}<0$.

\section{EMPIRICAL ANALYSIS}

\section{A. Sample Selection and Data Source}

Our sample selects the data from 2009 to 2018. The stock daily yield data, industry return rate, A-share market daily yield and B-share market daily yield and shareholding ratio data are all from CSMAR database. The H-share market daily return rate and the actual controller nature are derived from the Wind database, and the control variable data is derived from the RESSET database. The data processing software in this paper is EXCEL and Stata13.1.

\section{B. Analysis of Regression Results}

1) Equity concentration and stock price synchronization: Using the non-equilibrium panel data of listed companies in China from 2009 to 2018, the results are estimated by the previous model, and the following regression results are

\begin{tabular}{|c|c|c|c|c|}
\hline & SYNCH & SYNCH & SYNCH & SYNCH \\
\hline & H1a & H1b & H1a & H1b \\
\hline \multirow{2}{*}{ tophold } & $-0.011 * * *$ & $-0.011 * * *$ & & \\
\hline & $(0.00)$ & $(0.00)$ & & \\
\hline \multirow{2}{*}{ tophold $^{2}$} & $0.004 * *$ & $0.004 * *$ & & \\
\hline & $(0.03)$ & $(0.03)$ & & \\
\hline \multirow{2}{*}{$D I F$} & & & $-0.009 * * *$ & $-0.247 * * *$ \\
\hline & & & $(0.00)$ & $(0.03)$ \\
\hline \multirow{2}{*}{$D I F^{2}$} & & & $0.003 * *$ & $0.048 * *$ \\
\hline & & & $(0.04)$ & $(0.02)$ \\
\hline \multirow{2}{*}{$B A L A N C E$} & $-0.235^{* *}$ & $-0.213^{* * *}$ & $-0.305^{* *}$ & $-0.002 * * *$ \\
\hline & $(0.02)$ & $(0.01)$ & $(0.03)$ & $(0.005)$ \\
\hline \multirow{2}{*}{ dumcontrol } & & $0.038 * *$ & & $0.022 * * *$ \\
\hline & & $(0.02)$ & & $(0.01)$ \\
\hline Control variable & control & control & control & control \\
\hline Industry & Yes & Yes & Yes & Yes \\
\hline Year & Yes & Yes & Yes & Yes \\
\hline \multirow{2}{*}{ cons } & $-2.508 * * *$ & $-2.906 * * *$ & $-2.723 * * *$ & $-3.139 * * *$ \\
\hline & $(0.58)$ & $(0.55)$ & $(0.58)$ & $(0.55)$ \\
\hline$R$-squared & 0.461 & 0.458 & 0.461 & 0.457 \\
\hline$N$ & 16787 & 16787 & 16787 & 16787 \\
\hline
\end{tabular}
obtained. "Table II" is the result of regression of the stock price synchronization of the A-share market. "Table III" is the regression result of the stock price synchronization index listed on the foreign market.

TABLE II. Regression Results with SNYCH AS the Stock PRICE SynCHronizATION INDEX

a. Note: $\mathrm{P}$ value in parentheses, the same table below. 
TABLE III. Regression Results with SNYCHabH as the Stock Price SynChronization Index

\begin{tabular}{|c|c|c|c|c|}
\hline & SYNCHabh & SYNCHabh & SYNCHabh & SYNCHabh \\
\hline & H1a & H1b & H1a & H1b \\
\hline \multirow{2}{*}{ Tophold } & $-0.013 * * *$ & $-0.013 * * *$ & & \\
\hline & $\begin{array}{l}(0.00) \\
\end{array}$ & $(0.00)$ & & \\
\hline \multirow[b]{2}{*}{ Tophold $^{2}$} & $0.004 * *$ & $0.004 * *$ & & \\
\hline & $(0.03)$ & $(0.03)$ & & \\
\hline \multirow{2}{*}{$D I F$} & & & $-0.012 * * *$ & $-0.010^{* * *}$ \\
\hline & & & $(0.00)$ & $(0.00)$ \\
\hline \multirow{2}{*}{$D I F^{2}$} & & & $0.003 * *$ & $0.003^{* * *}$ \\
\hline & & & $(0.04)$ & $(0.04)$ \\
\hline \multirow{2}{*}{$B A L A N C E$} & $-0.297 * * *$ & $-0.277 * * *$ & $-0.390^{* * * *}$ & $-0.343^{* * *}$ \\
\hline & $(0.02)$ & $(0.02)$ & $(0.03)$ & $(0.03)$ \\
\hline \multirow{2}{*}{ Dumcontrol } & & 0.040 & & 0.028 \\
\hline & & $(0.03)$ & & $(0.03)$ \\
\hline Control variable & control & control & control & control \\
\hline Industry & Yes & Yes & Yes & Yes \\
\hline Year & Yes & Yes & Yes & Yes \\
\hline \multirow{2}{*}{ cons } & $-7.066^{* * *}$ & $-6.610 * * *$ & $-7.312 * * *$ & $-6.871^{* * *}$ \\
\hline & $(0.59)$ & $(0.57)$ & $(0.58)$ & $(0.57)$ \\
\hline$R$-squared & 0.514 & 0.513 & 0.512 & 0.511 \\
\hline$N$ & 16787 & 16787 & 16787 & 16787 \\
\hline
\end{tabular}

After the Hausman test of the model, it was decided to use the panel fixed effect for regression. Next is a detailed analysis of the regression results.

It can be seen from "Table II" and "Table III": First, for the indicator tophold of the equity concentration degree, the stock price synchronicity among the listed companies in the A shares, $\mathrm{B}$ shares and $\mathrm{H}$ shares is a concave function relationship, and The squared coefficient is greater than zero, and the primary term coefficient is less than zero, both of which are significant, that is, positive U-shaped. It is in line with H1a's assumptions; others may think that as the equity gap between shareholders increases, the power of the largest shareholder may become more concentrated. Therefore, our other equity concentration index DIF is used as a surrogate variable to regress. The results still show that the quadratic coefficient is significantly positive, the first term coefficient is significantly negative, and the result is the same as the tophold index. Second, in these eight regression equations, the coefficient of the equity balance indicator BALANCE has been significantly negative, indicating that the higher the equity balance, the lower the stock price synchronicity. Third, the actual controller property in the equation dumcontrol is significantly positive at the $1 \%$ confidence level when returning with $\mathrm{SNYCH}$ as an indicator, indicating that when the actual controller of the company is related to the government, the stock price is highly synchronized, and the hypothesis $\mathrm{H} 1 \mathrm{~b}$; In line with the SNYCHabh index, the coefficient is positive, but it is no longer significant. It may be that in the foreign market, due to regulatory or investor protection measures, the government are no longer a factor that restricts stock price synchronicity.
"Table II" and "Table III" confirm the previous hypotheses $\mathrm{H} 1 \mathrm{a}$ and $\mathrm{H} 1 \mathrm{~b}$, indicating that stock price synchronicity is a positive U-shaped function relationship that decreases first and then increases with the increase in equity concentration, and when the actual controller of the company is related to the government, the stock price is highly synchronized.

2) Dual listing and stock price synchronicity: According to column (1) and column (2) of "Table IV" is the study of the impact of dual listing on stock price synchronicity. It can be clearly seen that the dummy variable coefficients representing the B-share and $\mathrm{H}$-share listings are significantly negative, and the coefficients estimated by SNYCHabh are less than the SNYCH indicator. The obtained coefficient indicates that the dual listing is effective and low in stock price synchronicity, which is in line with the hypothesis $\mathrm{H} 2 \mathrm{a}$, which proves that when the foreign shareholding is held, it can effectively promote the capitalization of the company's trait information into the stock price, thereby reducing the stock price synchronicity. On the other hand, when using SNYCHabh as an indicator for regression, it can be clearly seen that dum $\mathrm{AB}$ is -0.592 and dumAH is -0.788 . The listed companies in the $\mathrm{H}$-share market have lower share price synchronicity than the Bshare listed companies, which is in line with the hypothesis $\mathrm{H} 2 \mathrm{~b}$. It verifies the influence of relevant scholars on the synchronicity of stocks at the institutional level - the Hong Kong market is more perfect - mature markets are less synchronised than emerging markets.

The regression results in columns (1) and (2) of "Table IV" visually show the hypothesis that $\mathrm{H} 2 \mathrm{a}$ and $\mathrm{H} 2 \mathrm{~b}$, foreign 
holdings do have low stock price synchronicity, and at the institutional level, the more mature markets, the lower the stock price synchronicity.

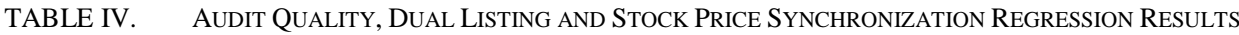

\begin{tabular}{|c|l|l|l|l|}
\hline & \multicolumn{1}{|c|}{ SNYCH } & \multicolumn{1}{c|}{ SNYCHabh } & \multicolumn{1}{c|}{ SNYCH } & SNYCHabh \\
\hline & \multicolumn{1}{|c|}{ H2 } & \multicolumn{1}{c|}{ H2 } & \multicolumn{1}{c|}{ H3 } & H3 \\
\hline \multirow{2}{*}{ Dumab } & $-0.182^{* * *}$ & $-0.592^{* * *}$ & & \\
\cline { 2 - 5 } & $(0.05)$ & $(0.05)$ & & \\
\hline \multirow{2}{*}{ Dumah } & 0 & $-0.788^{* * *}$ & & \\
\cline { 2 - 5 } & $(0.05)$ & $(0.05)$ & & $-0.058^{* * * *}$ \\
\hline \multirow{2}{*}{ Dadtunit } & & & $-0.037 *$ & $(0.02)$ \\
\hline \multirow{2}{*}{ Audit } & & & $-0.052^{* * *}$ & $-0.060^{* * *}$ \\
\hline & & & $0.02)$ & $(0.02)$ \\
\hline Control variable & control & control & control & control \\
\hline Industry & Yes & Yes & Yes & Yes \\
\hline Year & Yes & Yes & Yes & Yes \\
\hline \multirow{2}{*}{ cons } & $-3.598^{* * *}$ & $-7.585^{* * *}$ & $-3.039^{* * *}$ & $-7.684^{* * *}$ \\
\hline & $(0.55)$ & $(0.55)$ & $(0.59)$ & $(0.59)$ \\
\hline \multirow{2}{*}{-squared } & 0.4520 & 0.5035 & 0.450 & 0.502 \\
\hline \multirow{2}{*}{$\boldsymbol{N}$} & 16787 & 16787 & 16788 & 16788 \\
\hline
\end{tabular}

3) Audit quality and stock price synchronization: According to column (3) and column (4) of "Table IV" is the regression result with audit quality and financial report quality as the main explanatory variables. In the table, the dumdadtunit coefficient of the audit quality is significantly negative, indicating that under the same conditions, when the company selects the accounting firm with high reputation, reputation and high audit quality, the company's stock price synchronization is more low. In addition, for the financial statements published by listed companies each year, the variable audit coefficient is also significantly negative, indicating that the higher the company's financial reporting quality, the lower the company's stock price synchronization. Better accounting firms and higher quality financial statements mean that public disclosure of more effective information has played a positive role in gaining trust from outside investors and improving information asymmetry.

The regression of audit quality and financial statement quality accurately and accurately verifies H3's hypothesis. The higher the auditing company's financial reporting ranks, the lower the company's stock price synchronicity.

4) Full model regression: After discussing the effects of equity concentration, dual listing and audit quality on stock price synchronicity, all the research variables in the article were included in the full model regression. Considering that the fixed effect cannot test variables that do not change during the panel period, the random effect model is used in the full model regression. "Table V" shows that the goodness of fit of the full model regression is still good, and the positive and negative signs and significance of the coefficient of equity concentration, dual listing and audit quality are consistent with the previous model regression results. The conclusion is the same as the previous one: there is a concave function relationship between equity concentration and stock price synchronization. As the concentration of equity increases, the stock price synchronization first decreases and then rises; when the actual controller of the company belongs to the state-owned enterprise, the stock price synchronization Higher; dual listing significantly reduces stock price synchronicity, and the more mature Hong Kong market has the lowest price synchronicity; when audit quality and financial reporting quality are high, the company's stock price synchronization is small.

TABLE V. Full Model REgRESSION Results

\begin{tabular}{|c|c|c|}
\hline & SNYCH & SNYCHabh \\
\hline & Model 1 & Model 2 \\
\hline \multirow{2}{*}{$D I F$} & $-0.007 * * *$ & $-0.010 * * *$ \\
\hline & $(0.00)$ & $(0.00)$ \\
\hline \multirow{2}{*}{$D I F^{2}$} & $0.000^{\text {** }}$ & $0.000 * * *$ \\
\hline & $(0.00)$ & $(0.00)$ \\
\hline \multirow{2}{*}{ BALANCE } & -0.248 *** & $-0.326^{* * *}$ \\
\hline & $(0.03)$ & $(0.03)$ \\
\hline \multirow{2}{*}{ Dumcontrol } & $0.058^{* * * *}$ & $0.117 * * *$ \\
\hline & $(0.02)$ & $(0.02)$ \\
\hline \multirow{2}{*}{ Dumab } & $-0.216^{* * *}$ & $-2.848 * * *$ \\
\hline & $(0.05)$ & $(0.05)$ \\
\hline \multirow{3}{*}{ Dumah } & -0.0160 & -0.830 *** \\
\hline & $(0.05)$ & $(0.05)$ \\
\hline & $(0.02)$ & $(0.02)$ \\
\hline $\begin{array}{c}\text { Control } \\
\text { variable }\end{array}$ & control & control \\
\hline Industry & Yes & Yes \\
\hline Year & Yes & Yes \\
\hline \multirow{2}{*}{ cons } & $-3.158 * * *$ & $-7.007 * * *$ \\
\hline & $(0.55)$ & $(0.55)$ \\
\hline$R$-squared & 0.457 & 0.510 \\
\hline$N$ & 16787 & 16787 \\
\hline
\end{tabular}




\section{CONCLUSION}

We empirically analyze the relationship between stock price synchronicity and shareholding concentration, foreign shareholding (dual listing) and audit quality. The first shareholder shareholding ratio, the actual controller nature of the company and the audit quality are enterprise-level. Foreign ownership (double listing) is at the institutional level. It mainly got the following five conclusions.

First of all, there is indeed a concave function relationship between equity concentration and stock price synchronicity: there is a concave relationship between synchronicity and ownership concentration: as the concentration of equity increases, the stock price synchronization gradually decreases to a certain threshold. After that, when the actual controller of the company is related to the government, the stock price is more synchronized. Third, the foreign shareholding (double listing) has increased the content of the effective information in the company's stock price and realized the stock price synchronicity. Fourth, Hong Kong's capital market is more perfect. The company's stock price is the lowest in both Ashare and $\mathrm{H}$-share listed companies. The Hong Kong market has greater binding force and supervision. Fifth, the stock price synchronization is high. The auditing unit selected by the company, that is, the accounting firm, is also closely related. When the audit quality is higher, the stock price synchronization is lower.

There is still a long way to go in the development of China's securities market, but the exploration is a powerful proof that the capital market is more effective and can be worked through both the enterprise and market levels. By appropriately increasing the concentration of ownership, encouraging foreign investment into shareholdings, improving audit quality, and doing market regulation and investor protection, this will help achieve this goal.

\section{REFERENCES}

[1] Gul F A, Kim J B,Qiu A A. Ownership concentration, foreign shareholding, audit quality, and stock price synchronicity :Evidence from China [J]. Journal of Financial Economics, 2010, 95(3): 425-442.

[2] Chan K, Hameed A. Stock price synchronicity and analyst coverage in emerging markets [J]. Journal of Financial Economics, 2006, 80(1): 115-147.

[3] An H, Zhang T. Stock price synchronicity, crash risk, and institutional investors [J]. Journal of Corporate Finance, 2013, 21: 115 .

[4] Hasan, Song L, Wachtel P.Institutional development and stock price synchronicity: Evidence from China [J]. 2013.

[5] Roll R . $R^{2}$.Journal of Finance, 1998(43), 541-566.

[6] Durnev, Morck, Yeung et al. Does Greater Firm-Specific Return Variation Mean More or Less Informed Stock Pricing? [J]. Journal Of Accounting Research, 2008(5):797 836.

[7] Dasgupta, Gan,Gao. Does Lower $R^{2}$ Mean More Informative Stock Prices? Theory and Evidence [Z]. Hong Kong: Hong Kong University of Science and Technology, 2008.

[8] Doidge C., Karolyi, G.A,Stulz R. Why are foreign firms listed in the U.S. worth more [J]. Financial Economics, 2004, 71: 205-238.
[9] Gregory D , Kane, Uma Velury. The Impact of Managerial ownership on the Likelihood of Provision of High Quality Auditing Services [J]. Review of Accounting and Finance,2005,4,86-108.

[10] You Jiaxing, Zhang Junsheng, Jiang Wei. The Synchronization of Institutional Construction, Corporate Traits and Stock Price Fluctuation - Based on the Perspective of $\mathrm{R}^{\wedge} 2$ Research [J] Economics (Quarterly), 2006, (6).

[11] Jin Zhi. New accounting standards, accounting information quality and stock price synchronization accounting research [J]. Finance Communications, 2010, (7)

[12] Yuan Zhizhu, Yan evening. Institutional environment, corporate governance and stock price information content [J]. Management Science, 2009, (1).

[13] Li Zengquan. Synchronization of ownership structure and stock price - data from Chinese stock market [J].China Accounting and Finance Research, 2005, (3).

[14] Zhang Xueyong, Liao Li. Equity division reform, voluntary information disclosure and corporate governance. Economic research [J]. 2010, (4):28 39.

[15] You Jiaxing, Jiang Wei, Li Bin. An Empirical Analysis of the Synchronization of Chinese Listed Companies' Transparency and Stock Price Fluctuation [J].Zhongda Management Research.2007,(1).

[16] Mao Yiying. Research on the relationship between equity concentration, dual listing and stock price synchronization [D]. Master's thesis of Zhejiang University, 2010.

[17] Wang Yumei, Wang Yaping. How institutional investors influence the information efficiency of the market - the economic evidence machine from China [J]. Financial Research, 2011, (10).

[18] Li Shuangfei, Chen Shou. The Stock Information Transmission of Mainland Companies in Hong Kong and the United States [J]. Financial Teaching and Research,2008,(01) .

[19] Wang Wei, Hu Ying, Xiao Wei. Discussion on Auditing Quality and Scale of Accounting Firms [J]. Finance and Accounting News, 2009(9), 29-30 